УДК 328

\title{
A.A. Пасc
}

\section{ВЗАИМОДЕЙСТВИЕ ГОСУДАРСТВЕННЫХ ОРГАНОВ И БИЗНЕС-СТРУКТУР В РЕСПУБЛИКЕ КАЗАХСТАН НА ЗАВЕРШАЮЩЕМ ЭТАПЕ ПРЕЗИДЕНТСТВА Н.А. НАЗАРБАЕВА}

Рассматриваются взаимоотношения чиновников и предпринимателей с точки зрения снижения административных барьеров, укрепления законности в хозяйственной сфере и повышения активности бизнес-сообщества. Описана многоконтурная система центральных и региональных республиканских органов, регулировавших экономические процессы. Уделено внимание роли негосударственного сектора в налаживании конструктивного сотрудничества между частными фирмами и бюджетными учреждениями. Проанализированы сильные и слабые стороны борьбы с коррупционными правонарушениями и проявлениями недобросовестной конкуренции. Показаны мероприятия по преодолению дискреционных решений, упорядочению организации налоговых проверок и контрольных ревизий. Приведены примеры прессинга коммерсантов должностными лицами, злоупотреблявшими своими полномочиями. Проанализированы возможности открытых электронных порталов, которые помогали эффективно противостоять подобным попыткам. Отдельно представлены усилия властей по упорядочению и упрощению таможенных процедур. Перечислены меры, позволившие существенно облегчить доступ для предприятий различных форм собственности к участию в тендерах на государственные закупки. Сформулированы предложения, призванные способствовать ослаблению криминогенных факторов в деятельности бизнесменов и госслужащих.

Ключевые слова: Республика Казахстан, Президентство Н.А. Назарбаева, органы государственной власти, бизнес-структуры, оптимизация делового климата, снижение коррупционных рисков.

DOI: 10.35634/2587-9030-2021-5-2-186-194

\section{Правильная ссылка на статью:}

Пасс А.А. Взаимодействие государственных органов и бизнес-структур в Республике Казахстан на завершающем этапе президентства Н.А. Назарбаева // Вестн. Удм. ун-та. Социология. Политология. Международные отношения. 2021. Т. 5, вып. 2. С. 186-194. https://doi.org/10.35634/ 2587-9030-2021-5-2-186-194.

\section{Введение}

Не секрет, что коррупция отчасти объясняется готовностью некоторых предпринимателей нести дополнительные расходы в виде «материального стимулирования» чиновников, для того чтобы быстро преодолевать административные барьеры, нейтрализовывать своих соперников, уходить от налогов и тем самым гарантированно добиваться узкоэгоистических утилитарных целей. Этот асоциальный императив противоречит стратегической линии современного Казахстана в отношении бизнеса, государственно-частного партнерства и добросовестной конкуренции, которая предусматривает формирование устойчивого среднего класса, создание высокотехнологичных производств и развитие соответствующей инфраструктуры.

\section{Теоретические основания}

После распада СССР в бывших союзных республиках, в том числе и в Казахстане, началось становление новой государственности. Этот процесс протекал в условиях демократического транзита, перехода к рыночной экономике и сопровождался масштабной революцией институтов. В результате в незападных модернизирующихся обществах сложилась так называемая анклавная структура, имеющая двойственную природу. С одной стороны, у политически и экономически развитых стран активно заимствовались доказавшие свою эффективность современные учреждения и нормы. С другой стороны, в странах-реципиентах продолжали сохраняться отношения, связанные с традиционным жизненным укладом [1]. Главная опасность для государств, вступивших в трансформационный период, заключается в том, что решения ангажированных политиков могут определяться не соображениями «общей пользы», а исключительно интересами аффилированной компании или бюрократии различной ведомственной принадлежности, значимой в политическом отношении. В этом случае власть 
Взаимодействие государственных органов и бизнес-структур в Республике Казахстан...

теряет способность проводить прогрессивные преобразования. Отсюда вытекает необходимость целенаправленно вытеснять неформальные институции и эгоистические корыстные мотивы на периферию общественной жизни, с тем чтобы они перестали играть значимую роль в политическом и социально-экономическом процессах.

\section{Метод}

При изучении существующих приемов и практики внедрения цивилизованных принципов управления смешанной экономикой применялись институциональный, праксеологический, исторический и компаративный методы, а также описательно-индуктивный анализ правовых и обыденных институтов. Использовалась количественная и качественная интерпретация данных официальной статистики по числу и составу коррупционных деяний, объему неформальных трансакций, являющихся базой для выстраивания теневых схем.

\section{Результаты}

Орган, ответственный за развитие промышленности, торговли и услуг в РК, - Министерство национальной экономики (МНЭ), учреждено 24 сентября 2014 г. согласно постановлению Правительства страны № 1011 [10]. Нормативно-правовое обеспечение возложено на Комитет по регулированию естественных монополий и защите конкуренции, которому подотчетен Департамент развития предпринимательства. В круг полномочий последнего входит: участие в формировании и реализации единой государственной политики поддержки бизнеса; координация усилий местных органов управления; сотрудничество с другими учреждениями и общественными объединениями, в том числе по антикоррупционной проблематике; рассмотрение и принятие необходимых мер по жалобам бизнесменов на действия чиновников, мешающих законной хозяйственной деятельности.

Контрольные функции сосредоточены в Министерстве финансов. Посредством своих ведомствкомитетов оно следит за соблюдением госорганами и субъектами предпринимательства правил осуществления госзакупок и операций с деньгами и/или иным имуществом; выявляет и расследует налоговые, таможенные и финансовые правонарушения; противодействует теневой экономике. Общий надзор за законностью в социально-экономической сфере находится в компетенции Генеральной прокуратуры.

В системе региональной исполнительной власти - акиматах областей и городов Алматы и Астаны (ныне г. Нур-Султан) - образованы Управления предпринимательства. Нижним звеном вертикальной административной иерархии, регулирующим взаимодействие с частными предприятиями, являются аппараты акимов городов и районов республики, которые опираются на отделы экономики и бюджетного планирования или отделы экономики и финансов. Именно они занимаются претворением в жизнь целевых мероприятий и программ, субсидируемых из местных бюджетов.

Финансовая, информационно-аналитическая и материально-техническая поддержка предпринимательства возложена и на специально созданные государством компании. Всего их шесть: АО «Центр инжиниринга и трансферта технологий», АО «Корпорация по развитию и продвижению экспорта "Kaznex"», АО «Фонд развития предпринимательства «Даму», АО «Национальный инновационный фонд», АО «Инвестиционный фонд Казахстана», АО «Банк Развития Казахстана». Важную роль играют технопарки, бизнес-инкубаторы, промышленные зоны.

Для налаживания обратной связи Президент Н.А. Назарбаев своим Указом создал Совет национальных инвесторов, предназначением которого являлась консолидация коммерческих ассоциаций и союзов на республиканском уровне, с тем чтобы они принимали активное участие в выработке рекомендаций по устранению административных препонов и общему улучшению делового климата в стране [22].

По поручению Лидера нации был введен институт уполномоченного по защите прав предпринимателей, или бизнес-омбудсмена (УЗПП). Глава 28 Предпринимательского кодекса, принятого Мажилисом 1 января 2016 г., подробно раскрывает его правовой статус. Он назначался на должность главой государства и отчитывался перед ним; не имел права заниматься политикой; обязывался на период пребывания в должности передать в доверительное управление принадлежащее ему имущество; не мог работать по найму в других организациях (исключение делалось для преподавательской, научной или иной творческой деятельности). 
Ключевая функция уполномоченного заключалась во внесении в государственные органы, прокуратуру, Администрацию Президента Республики Казахстан предложений по восстановлению нарушенных прав субъектов предпринимательства, вплоть до приостановления подзаконных нормативных актов, и привлечению к ответственности причастных к этому должностных лиц. Бизнесомбудсмен мог в установленном законом порядке обращаться с исковым заявлением в суд [13]. Как правило, он работал в тесном контакте с Национальной палатой предпринимателей (НПП) «Атамекен», ее областными отделениями, а также департаментами по защите законных прав предпринимателей, имеющимися в надзорных и исполнительных органах власти. Большим подспорьем являлось сотрудничество с Республиканским общественным советом по поддержке предпринимательства при партии «Нур Отан».

\section{Обсуждение}

В июне 2016 г. по инициативе общественности в Астане был проведен форум, посвященный роли надзорных органов в улучшении делового климата. В его работе приняли участие депутаты парламента, представители Администрации Президента, правительства, центральных органов управления, неправительственного сектора и эксперты по защите прав и интересов бизнеса. В своем выступлении Генеральный прокурор РК Ж. Асанов подчеркнул, что одной из главных задач данного мероприятия является реализация поручения главы государства, изложенного в Стратегии «Казахстан 2050», об увеличении к 2030 г. доли малого и среднего бизнеса в экономике путем создания для него благоприятных условий. В ходе заседания состоялось обсуждение ряда острых тем, волнующих бизнес-сообщество [7].

Особое внимание уделялось проблеме строгого соблюдения законодательства при регистрации сообщений о правонарушениях, в том числе коррупционных, якобы допущенных предпринимателями. Реалии оказались таковы, что по рапорту работника органа уголовного преследования, имеющего доступ к Единому реестру досудебного расследования (ЕРДР), любые сигналы (от заявителя, из СМИ и даже анонимные) были вполне достаточным поводом для вовлечения коммерсантов в уголовный процесс с использованием всего арсенала следственных действий [12]. Для них это оборачивалось потерей репутации, убытками и даже ликвидацией дела. Между тем уполномоченный по защите прав предпринимателей РК Палымбетов Б.А., проанализировав по итогам 2015 г. уголовное делопроизводство по экономическим преступлениям, пришел к неутешительному выводу: из 8857 возбужденных дел только 1914 были направлены в суд. Значит, в 80 \% случаев бизнесмены подвергались необоснованным гонениям [9].

Статистика говорила о том, что в такой форс-мажорной ситуации более трети юридических лиц вынужденно прекращали деятельность и увольняли персонал. Столь серьезные угрозы заставляли кое-кого искать «нестандартные варианты выхода из кризиса», включая дачу взятки. Понятно, что формулировка «информация не подтвердилась», тут не помогала. Имелся налицо коррупционный риск, который предстояло устранить.

Хорошо иллюстрирует вышесказанное происшествие с хлопкодобывающей компанией ТОО «Яссы-групп». В 2014 г. налоговый департамент Южно-Казахстанской области предъявил ей претензии на сумму 194, 4 млн тенге. Основание - нарушение трансфертного ценообразования при поставках хлопка в Россию. Ориентиром для инспекторов послужили рыночные котировки стран ЮгоВосточной Азии, хотя казахстанская продукция в указанный регион никогда не поставлялась. На товарищество завели уголовное дело, которое длилось полтора года. За это время заготовки сырья упали в 6 раз, оборот - в 4 раза. 104 человека остались без работы. Бизнесмены разрешили конфликт в правовом поле, подключив к разбирательству НПП «Атамекен». Было составлено совместное обращение в Судебную коллегию по гражданским делам Верховного суда РК, и та не нашла в деле состава преступления [15].

Возвращение доследственной проверки, о чем ходатайствуют правозащитники, вряд ли спасет предпринимателей «от накатов». ЕРДР, безусловно, нужен, и он уже оправдал себя при раскрытии очевидных преступлений по горячим следам, без всякой волокиты. Это тем более необходимо, когда коррупционное преступление уже совершено и промедление чревато утратой доказательств, имущества, бегством преступника за границу. В то же время в адрес правоохранительных органов нередко поступали сообщения о подозрительных случаях и ситуациях, где без аудита, ревизий и оперативных меро- 
Взаимодействие государственных органов и бизнес-структур в Республике Казахстан...

приятий сложно дать оценку. В таких случаях Уголовно-процессуальный кодекс РК позволял сразу перенаправлять сигнал в уполномоченный госорган, не фиксируя его в Едином реестре. Иными словами, если де-юре доследственная проверка в отношении экономических правонарушений, которые зачастую связаны с фактами коррупции, была упразднена, то де-факто она по-прежнему имела место.

Но тут вновь появлялись дискреционные моменты. Анонсировав проверку согласно поступившей информации и обнаружив признаки коррупционного деяния, управомоченное должностное лицо обязывалось принять меры для продолжения расследования. Однако оно могло и не проводить проверку, сославшись, например, на отсутствие у подозреваемого административно-распорядительных функций, корыстных мотивов или нанесенного ущерба [8], и тем самым вольно или невольно способствовать укрытию преступления.

Налоговые службы зачастую специально провоцировали уголовное преследование коммерческой структуры ради получения беспрепятственного доступа к ее бухгалтерским документам. Для проведения внеплановой ревизии требовалось доказать ее обоснованность, а это - кропотливая работа. Если аргументы слабые, прокуратура опротестовывала результат. А так, через налаживание «взаимопонимания» с оперативником, можно было совместными усилиями держать бизнес «под колпаком». Наверное, целесообразно впредь в каждом подобном случае, касающемся значимого субъекта предпринимательской деятельности, получать санкцию прокурора, специализирующегося на коррупционных делах. Иначе возникают предпосылки для такого негативного явления, как рейдерство.

Иногда узкими местами в законодательстве пользовались недобросовестные конкуренты, обвиняя соперника в мошенничестве с намерением парализовать его деятельность. Поэтому, прежде чем вносить эти заявления в ЕРДР, необходимо изучать их на предмет наличия договорных отношений между конфликтующими сторонами. Если они есть, то переадресовывать материалы в гражданский суд. Пусть там решают, подпадает ли данное дело под криминальную статью. В любом случае регистрация коррупционных преступлений, как, впрочем, и укрывательство последних, должна стоять на особом контроле в надзорных инстанциях всех уровней.

Беспокойство владельцев частных фирм вызывало то, что в Казахстане не регламентировался должным образом порядок организации проверок. В 1990-е гг. рейды налоговиков были массовыми и практически неконтролируемыми, с 1999 г. введена обязательная регистрация. В течение 2011-2015 гг. их число сократили в 4 раза - с 30 тыс. до 7 тыс. в месяц. Процент подвергнутых ревизии предприятий снизился с $50 \%$ до $3 \%$. Тем не менее проверками малого и среднего бизнеса продолжал заниматься 61 госорган. Прессинг в той или иной степени сохранялся ${ }^{1}$.

Вот пример. В феврале 2015 г. в Восточно-Казахстанской области (ВКО) бывший фармацевт ТОО «ЕвроАзияФарм» Е. Лихачева, специалист с высшим профессиональным образованием и солидным стажем, зарегистрировалась как индивидуальный предприниматель. Она открыла свой рецептурный отдел - второй в г. Усть-Каменогорске, после «Аптеки 101», принадлежащей упомянутому ТОО. Но заместитель руководителя Департамента Комитета контроля медицинской и фармацевтической деятельности по ВКО Министерства здравоохранения и социального развития РК Л. Кусябгалиева и собственница «ЕвроАзияФарм» К. Калиаскарова под надуманными предлогами инициировали проверки ИП Лихачевой, по итогам которых были выписаны большие штрафы. Пострадавшая обратилась с жалобой в региональную палату предпринимателей, а та - в областную прокуратуру.

Обнаружилось, что у Л. Кусябгалиевой имелся личный интерес: ее родственники, владеющие сетью аптек в г. Семей, получали от ТОО «ЕвроАзияФарм» лекарства для розничной торговли. Когда сговор чиновницы и бизнесвумен удалось раскрыть, против них были возбуждены уголовные дела.

\footnotetext{
${ }^{1}$ По мнению авторов доклада «Добропорядочность бизнеса в Восточной Европе и Центральной Азии», опубликованного ОЭСР в 2016 г., в Казахстане имеют место: злоупотребления в области планирования проверок со стороны контролирующих органов; ошибки в классификации предприятий на основе подверженности рискам (юридические лица с низким уровнем риска были классифицированы как предприятия среднего риска); проверки недавно созданных организаций, несмотря на законодательный запрет таких проверок; необоснованное продление проверок и недостаточный контроль инспекционной деятельности. Обычным видом злоупотреблений является применение произвольных штрафов. Иностранные компании сообщают о том, что власти на местном и национальном уровне произвольно налагают экологические штрафы, которые затем перечисляются в бюджет, а не напрямую компенсируют какой-либо предполагаемый ущерб окружающей среде. В результате, как утверждается, экологические штрафы оцениваются как предназначенные для получения дополнительного дохода, а не для наказания компаний за нарушение природоохранного законодательства [2. С. 60]. - Прим. aвm.
} 
Первой вменили злоупотребление должностными полномочиями, выразившееся в ущемлении прав и законных интересов граждан и организаций. Ей назначили три года ограничения свободы, штраф 4 млн тенге и пожизненное лишение права занимать должности на госслужбе. Действия второй антикоррупционная служба квалифицировала как подстрекательство к совершению уголовного правонарушения, воспрепятствование законной предпринимательской деятельности по предварительному сговору с должностным лицом, повлекшим причинение ущерба в особо крупном размере. Но в связи «с деятельным раскаянием» уголовное преследование в отношении К. Калиаскаровой было прекращено [21].

Чтобы подобные прецеденты не повторялись, государственные контрольно-ревизионные органы концентрировали свое внимание на предприятиях высокой группы риска (ПВГР $)^{2}$. Именно их в первую очередь включали в электронный сервис «Единый реестр проверок». В особой вкладке на сайте отражались: 1) стадия проверки; 2) вскрытые нарушения; 3) контактная информация для обратной связи, воспользовавшись которой каждый предприниматель может узнать, законно ли его проверяют. Практика показала действенность этого инструмента. В течение непродолжительного времени за разъяснениями обратилось свыше 1 тыс. субъектов бизнеса, и каждому третьему была оказана правовая помощь. За самоуправство и превышение полномочий наказали более 400 чиновников [17].

Известно, что деловые люди периодически нуждаются в тех или иных разрешениях: на отвод земельных участков, строительство, аренду и т. д. Искусственные административные преграды на этом пути, которые нельзя назвать иначе как завуалированным вымогательством денег, вызывают острое недовольство. Для их устранения Генеральная прокуратура РК совместно с НПП «Атамекен» и бизнес-омбудсменом взяла на вооружение тактику «создания экспериментальной ситуации». По просьбе конкретного предпринимателя отслеживался весь путь, который он должен пройти по коридорам власти.

Порой открывались неприглядные моменты. Так, отдел архитектуры г. Шымкента бесплатную госуслугу по выдаче архитектурно-планировочного задания поставил на коммерческие рельсы. На специальном стенде клерки разместили перечень документов, среди которых оказались материалы топографической съемки, карты-схемы, технические условия на инженерное обеспечение и проч. Было объявлено, что без них заявление рассмотрению не подлежит. А изготавливали их (и отнюдь не безвозмездно) целых пять фирм, принадлежавших супруге главного архитектора города. Безобразиям сразу положили конец [4].

Одна из болевых точек, мешавших плодотворному сотрудничеству государства и частного сектора, - несовершенство правовых норм. Немалую лепту в гармонизацию законодательства вносили депутаты и профессиональные эксперты. Но возможность высказать свое слово была предоставлена и деловому сообществу. Кому, как не его представителям, лучше знать о неприятных сюрпризах, которые таит в себе юридическая казуистика. Это полностью соответствует духу Концепции государственного регулирования предпринимательской деятельности до 2020 г., утвержденной Правительством РК 18 апреля 2014 г. [11] .

Для этого в Интернете создали общедоступный электронный формуляр и предусмотрели в нем три графы: название нормативно-правого акта; указание абзацев, пунктов или статей, вызывающих нарекание; краткая аргументация того, почему и как их надо изменить, с описанием случаев из собственной хозяйственной практики. Затем по каждому замечанию требовалось получить заключение компетентных государственных органов и вынести предложение на всеобщее обсуждение. Предлагаемая мера ускорила и конкретизировала работу по совершенствованию условий для ведения бизнеса в Республике Казахстан.

Тем не менее они не стали полностью свободными от коррупциогенных факторов. Много нареканий в адрес властей поступало от субъектов предпринимательства в отношении действующего порядка таможенного администрирования. В частности, не устраивали длительность и непрозрачность таможенных процедур, недостаточная инфраструктурная оснащенность контрольно-пропускных

\footnotetext{
${ }^{2}$ ПВГР - субъекты предпринимательской деятельности, чьи суммы уплаченных налогов и других обязательных платежей в бюджет к совокупному годовому доходу ниже среднеотраслевого значения за соответствующий период, а также осуществляющие операции с лжепредприятиями или заключающие фиктивные сделки. - Прим. aвm.

${ }^{3}$ В Концепции выражена идея передачи в бизнес-среду отдельных государственных функций регулирования предпринимательской деятельности с одновременным повышением ответственности предпринимателей за нарушения, повлекшие ушерб для потребителей. Предполагается исключить вмешательство государства в процесс производства и внутреннюю деятельность частных предприятий и сосредоточить госконтроль только на качестве и безопасности конечного продукта. - Прим. авт.
} 
Взаимодействие государственных органов и бизнес-структур в Республике Казахстан...

пунктов и зон оформления. К тому же Кодекс о таможенном деле устанавливал для уполномоченных органов необоснованно широкие дискреционные полномочия. Ничем не ограниченное право на истребование дополнительных документов, произвольное установление сроков проведения досмотра инспектором (законодательно они не определены), неурегулированность вопросов длительности и оснований для выездной проверки, а равно ее приостановки (к таковым может быть отнесена необходимость назначения дополнительной экспертизы $)^{4}$ создавали возможности для должностных злоупотреблений и разнообразного крючкотворства с целью получения мзды.

Для предпринимателей это оборачивалось срывом договорных обязательств и наложением на них штрафных санкций контрагентами. Многим проще было заплатить взятку за беспрепятственную таможенную очистку товаров. Так, по результатам опроса, проведенного в мае 2015 г. среди клиентов таможенных служб на 16 постах, ее размеры колебались в диапазоне 100-110 тысяч тенге [20]. Чувствуя себя ущемленными, коммерсанты обращались в суды с заявлениями об обжаловании незаконных действий должностных лиц при осуществлении таможенного контроля и, несмотря на то, что являлись «слабейшей» стороной, выигрывали каждое третье дело.

В настоящее время для обеспечения независимости, открытости и прозрачности рассмотрения жалоб по таможенным и налоговым спорам, для экономии времени и средств состав Апелляционной комиссии при Министерстве финансов расширен. В частности, туда включили независимых предста-

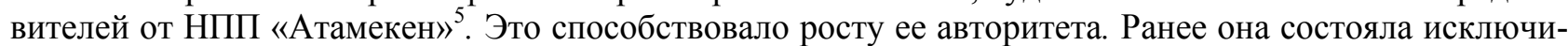
тельно из сотрудников Комитета госдоходов, чья мотивация выражалась в стремлении «защитить честь мундира».

Примером эффективного противодействия коррупции в таможенной сфере РК служит осуществление оригинального проекта под названием «Красота спасет мир». Его смысл заключался в создании центра таможенного оформления, состоящего исключительно из женщин, прошедших специальный отбор и психофизиологическое тестирование на полиграфе. В качестве опытного полигона определили таможенный пост «Астана-ЦТО» Департамента государственных доходов по г. Астана. За два месяца, прошедших с начала реализации проекта, его сотрудницы выполнили годовой план по финансовым поступлениям в казну. Это говорит о высоком потенциале данного нововведения и его скрытых резервах [3].

Уязвимым местом с точки зрения коррупционных проявлений традиционно считается сфера государственных закупок. Ниже на примере Управления по госзакупкам Южно-Казахстанской области показано, как организовывались серые схемы, позволявшие чиновникам сначала передавать подряды исключительно аффилированным или «прикормленным» фирмам, а потом, не опасаясь разоблачения, расхищать денежные средства путем завышения объемов выполненных работ и получения «откатов».

Материалы журналисту К. Лариной были предоставлены директором шимкентского ТОО «Верен» Г. Абишевой [5]. В 2015 г. товарищество, которое к тому времени работало на рынке строительства 15 лет, приняло участие в 15 -ти тендерах, в 2016 г. - в 12-ти. У него имелись необходимая техническая база, квалифицированные специалисты, лицензия первой категории, большой опыт в строительстве школ, больниц, детсадов, гидросооружений. Тем не менее все поданные заявки отклонялись. В качестве оснований фигурировали замечания, не указанные в протоколе предварительного допуска, которые по закону не могли выступать причинами для отвода. Неожиданно требовались технические паспорта на некоторые машины и механизмы, а также оборудование, отсутствующее в первоначальной ресурсной смете. Предъявлялись повышенные запросы к материально-трудовым ресурсам. Претензии не пояснялись, в лучшем случае давалась ссылка на ту или иную статью «действующего законодательства». В чем конкретно выражалось несоответствие кондициям, было совершенно непонят-

\footnotetext{
${ }^{4}$ По данным депутата Мажилиса, члена Совета по противодействию коррупции и теневой экономике Национальной палаты предпринимателей «Атамекен» А. Жамалова, нередки случаи, когда стоимость партии товаров, по которым она назначалась, составляла всего от 6 \$ до $200 \$[17]$.

${ }^{5}$ Международные эксперты оценивают роль общественных организаций и деловых ассоциаций в противодействии коррупции очень высоко и считают, что в отличие от большинства отдельных компаний они не ограничиваются собственными интересами оператора хозяйственной деятельности, а нацелены на достижение более широкого общественного блага. Ассоциации также могут служить средством, с помощью которого фирма, которая хочет воздерживаться от коррупции, будет уверена, что ее конкуренты не получат преимущества за счет продолжения незаконного взаимодействия с государственными служащими. Выделяют три основных способа, с помощью которых деловые ассоциации могут поддержать борьбу с коррупцией: призывая к коллективным действиям, продвигая реформы и укрепляя деловую этику внутри компаний [2. С. 19; 6. Р. 2, 3].
} 
но. В конце концов, в списке участников оставалась одна единственная компания, и конкурс объявляли несостоявшимся.

Попытки обжалования оказывались безрезультатными. В последних девяти случаях руководство «Верена» обращалось в КГД МФ. Ответы пришли только по четырем письмам, с задержкой в три месяца, когда договор с оставшимся кандидатом в подрядчики уже подписали и строительство началось ${ }^{6}$. Бизнесвумен высказывала убеждение, что опротестовывать неправомерные решения властей по тендерам просто невозможно.

Гульмира Абишева оказалась не одинока в своем недовольстве неправомерными действиями сотрудников областного управления по государственным закупкам ЮКО. С аналогичными жалобами в Республиканскую палату предпринимателей обращались руководители еще трех ТОО («Промстройсервис.Е», «Авто-Б.А.Н.», «Улмад»), чьи заявки тоже были отклонены под надуманными предлогами. С подачи РПП профильный комитет Минфина РК провел внутренний аудит, в ходе которого нашел нарушения и отменил итоги 7 конкурсов. Попутно были проанализированы все 49 тендеров 2016 г., в каждом из которых пытались зарегистрироваться от 8-ми до 10-ти участников. В 34 из них, т. е. в 70 \%, допуск получило лишь одно юридическое лицо, с которым впоследствии и было заключено соглашение.

Негативно-пристрастное отношение чиновников к потенциальным поставщикам старались пресекать. Виновных неоднократно подвергали штрафу в размере 100 МРП. Они его беспрекословно оплачивали, но продолжали заседать в конкурсных комиссиях и творить самоуправство. По-видимому, в отношении госслужащих, уличенных в протекционизме «своим» фирмам, целесообразно ставить вопрос о несоответствии занимаемой должности, а затем увольнять их по статье [19], коль скоро законом пока не предусмотрено более суровое наказание.

Отмеченными направлениями взаимодействие по линии «государство - бизнес» не исчерпывалось. С предпринимателями периодически контактировали областные департаменты: 1) Комитет по чрезвычайным ситуациям МВД РК (обеспечение пожарной безопасности); 2) Комитет государственного санитарно-эпидемиологического надзора Министерства здравоохранения РК (обеспечение санитарно-эпидемиологического благополучия населения); 3) Комитет экологического регулирования и контроля Министерства энергетики РК (обеспечение охраны окружающей среды). По данным социологического исследования «Деловой климат 2015», проведенного НПП «Атамекен», на факты коррупции в перечисленных учреждениях указали соответственно $20,23 \%, 24,39 \%, 15,92 \%$ опрошенных [16], что свидетельствовало о необходимости усиления контроля за их работой со стороны антикоррупционных органов, общественных организаций и рядовых граждан.

\section{Выводы}

Таким образом, частное предпринимательство в Казахстане при Президенте Н.А. Назарбаеве воспринималось как приоритетный объект социально-экономической политики. Его нужды и интересы обслуживал разветвленный госаппарат на уровне ведомств, акиматов, правозащитных институтов. Специальные службы несли ответственность за выявление и пресечение экономических преступлений. В целом управление бизнес-процессами было организовано на принципах многоконтурной системы, в которой различные элементы взаимодополняли друг друга, их функции диверсифицировались, а сигнал от одного активизировал деятельность остальных. Коррупционная составляющая в поведении чиновника и предпринимателя возникала, когда: 1) их мотивации пересекались (один выражал заинтересованность в административной ренте, а другой соглашался ее выплатить в обмен на протекционистские решения, позволяющие минимизировать текущие издержки или устранить добросовестных конкурентов); 2) чиновник сам являлся владельцем бизнеса, оформленного на доверенных или подставных лиц.

Снижение вероятности преступного сговора и конфликта интересов обеспечивалось постепенной трансформацией коррупциогенной среды в нейтральную. Для скорейшего достижения указанной цели необходимы расширение применения технических методов (электронная коммерция, видеонаблюдение за рабочими площадками, отслеживание делопроизводственной и учредительной документации на предмет выявления аффилированности и конечных бенефициариев заключенных контрактов) и опти-

\footnotetext{
${ }^{6}$ В случае отмены конкурса из-за отсутствия или отклонения «по объективным причинам» альтернативных предложений статья 29 Закона РК «О государственных закупках» позволяет заказчику приобретать товары и услуги способом из одного источника, самостоятельно определяя выбор последнего. Это удобная лазейка для комбинаторов во власти, «великих» и не очень. - Прим. авт.
} 
Взаимодействие государственных органов и бизнес-структур в Республике Казахстан...

мизация процедур (операционные алгоритмы, сводные каталоги результатов торгов, ротация должностных лиц, «оперативные эксперименты» в виде намеренного создания проблемной ситуации). От кадровых ошибок способен предохранить тщательный отбор сотрудников на должности с высоким коррупционным риском по критерию моральной устойчивости (глубинные интервью, тесты, проверка на полиграфе, подробные индивидуальные характеристики и психологические портреты). Внутреннему неприятию коррупции у госслужащих и хозяйствующих субъектов могли бы способствовать показательные репрессии и меры общественного воздействия в отношении провинившихся (увольнение, лишение лицензии, возбуждение и публичное рассмотрение уголовного дела в суде, штрафные санкции, исключение из профессионального сообщества или объединения, моральный остракизм).

В целом же то, что было сделано в РК в последние годы президентства Н.А. Назарбаева с точки зрения совершенствования условий для ведения бизнеса, положительно характеризовалось международными наблюдателями. В докладе Всемирного банка, вышедшем в 2016 г., два участника Стамбульского плана действий по борьбе с коррупцией - Казахстан и Узбекистан - названы самыми лучшими в данной номинации [14].

\section{СПИСОК ЛИТЕРАТУРЫ}

1. Богатуров А.Д. Понятие экономической политологии и особенности ее проблемного поля в России // Полис. 2011. № 4. С. 8-19.

2. Добропорядочность бизнеса в Восточной Европе и Центральной Азии. ОЭСР, 2016. 199 с.

3. Ергожин Д.Е. Итоги деятельности Комитета государственных доходов МФ РК за 2015 г. Доклад председателя КГД на Коллегии Министерства финансов Республики Казахстан 10 февраля 2016 г. [Электронный ресурс]. Комитет государственных доходов МФ РК. URL: http://kgd.gov.kz/ru/content/doklady-1 (дата обращения: 28.12.2016).

4. Курносова С. В Шимкенте из-за скандала уволился главный архитектор города. [Электронный ресурс]. Kazinform. Международное информационное агентство. 28 ноября 2016 г. URL: http://www.inform.kz/ru/vshymkente-iz-za-skandala-uvolilsya-glavnyy-arhitektor-goroda_a2721689 (дата обращения: 24.12.2016).

5. Ларина К. Конкурс для всех - допуск для одного. [Электронный pecypc]. Atameken business channel. 17 ноября 2016 г. URL: http://abctv.kz/ru/news/konkurs-dlya-vseh-dopusk-\%E2\%80\%93-dlya-odnogo (дата обращения: 27.12.2016).

6. Martini M. The role of business associations and chambers of commerce in the fight against corruption // Expert Answer (Anti-corruption Resource Centre U4). 2013. No. 394.

7. Надзор прокуратуры в сфере предпринимательства (содержание и приоритеты). [Электронный ресурс]. Nomad. Кочевник. URL: http://www.nomad.su/?a=3-201606150014 (дата обращения: 18.12.2016).

8. Овчинникова О.В. Признаки коррупционного преступления как основания для возбуждения уголовного дела // Проблемы права. 2015. № 2. С. 182.

9. Огни Мангистау. 2016, 25 июля.

10. Постановление Правительства Республики Казахстан от 24 сентября 2014 г. «Вопросы Министерства национальной экономики Республики Казахстан» (с изменениями и дополнениями по состоянию на 18.02.2017 г.). [Электронный ресурс]. Параграф. URL: http://online.zakon.kz/Document/?doc id=31611088 (дата обращения 22.03.2017).

11. Постановления Правительства РК за апрель 2014 года. [Электронный ресурс]. Правительство Республики Казахстан. Официальный сайт. URL: http://www.government.kz/ru/postanovleniya/postanovleniya-pravitelstvark-za-aprel-2014-goda/16516-ob-utverzhdenii-kontseptsii-gosudarstvennogo-regulirovaniya-predprinimatelskojdeyatelnosti-do-2020-goda.html (дата обращения: 30.12.2016).

12. Правила приема и регистрации заявления, сообщения или рапорта об уголовных правонарушениях, а также ведения Единого реестра досудебных расследований. Утверждены приказом Генерального Прокурора Республики Казахстан от 19 сентября 2014 г. № 89. Гл 2. [Электронный ресурc]. Tengry news. URL: https://tengrinews.kz/ zakon/generalnaya_prokuratura_respubliki_kazahstan/sud/id-V14W0009744/ (дата обращения: 18.12.2016).

13. Предпринимательский кодекс Республики Казахстан (с изменениями и дополнениями по состоянию на 26.07.2016 г.). [Электронный ресурс]. Параграф. URL: http://online.zakon.kz/Document/?doc_id=38259854 \#pos=1;-307 (дата обращения: 17.12.2016).

14. Реформы в сфере борьбы с коррупцией в странах Восточной Европы и Центральной Азии. Достижения и проблемы, 2013-2015 гг. ОЭСР, 2016. С. 22.

15. Рысбаева Ж. Хлопковая отрасль Казахстана под угрозой. [Электронный pecypc]. Otyrar. kz. Новости для Шымкента. URL: http://otyrar.kz/2016/03/xlopkovaya-otrasl-kazaxstana-pod-ugrozoj/ (дата обращения: 19.12.2016).

16. Социологическое исследование «Деловой климат - 2015». С. 14. [Электронный pecypc]. URL: http://palata.kz/ uploads/content/files/\%D0\%94\%D0\%B5\%D0\%BB\%D0\%BE\%D0\%B2\%D0\%BE\%D0\%B9\%20\%D0\%BA\%D0\% BB\%D0\%B8\%D0\%BC\%D0\%B0\%D1\%82-2015\%20\%D0\%B3.pdf.pdf (дата обращения: 29.12.2016). 
17. Таможня и бизнес: разговор начистоту. [Электронный ресурс]. Уполномоченный по защите прав предпринимателей Казахстана. Официальный сайт. 21 сентября 2016 г. URL: http://ombudsmanbiz.kz/rus/press-centr/ smi_ob_ombudsmene/?cid=0\&rid=124 (дата обращения: 27.12.2016).

18. Тезисы выступления Генерального прокурора Жакипа Асанова на форуме «Надзор прокуратуры в сфере предпринимательства». (г. Астана 14 июля 2016 г.). [Электронный ресурс]. Генеральная прокуратура Республики Казахстан. URL: http://m.prokuror.kz/rus/comment/reply/53768 (дата обращения: 19.12.2016).

19. Трудовой кодекс РК с изменениями и дополнениями от 06.04.2016 г. Нарушение условий заключения трудового договора. [Электронный ресурс]. URL: http://www.mikosoft.kz/trudovoy-codex-2016.html\#st_48 (дата обращения: 19.02.2017).

20. Туратбеков К. Уровень коррупции в таможенных органах Казахстана в 10 раз выше, чем в налоговых. [Электронный ресурс]. BNEWS KZ. 29 мая 2015 г. URL: http://bnews.kz/ru/news/obshchestvo/ uroven korruptsii_v_tamozhennih_organah_kazahstana_v_10_raz_vishe_chem_v_nalogovih-2015_05_29-1108459 (дата обращения: 27.12.2016).

21. Ушакова О. «Лекарственный» монополист из ВКО устраняет конкурентов. [Электронный ресурс]. Страна. 26 мая 2016 г. URL: http://abctv.kz/ru/news/lekarstvennyj-monopolist-iz-vko-ustranyaet-konkurentov (дата обращения: 18.12.2016).

22. Указ Президента РК «Об образовании Совета национальных инвесторов при Президенте Республики Казахстан» (с изменениями от 17.09.2014 г.). [Электронный ресурс]. Параграф. URL: http://online.zakon.kz/ Document/?doc_id=31535822\#pos=7;-286 (дата обращения: 17.12.2016).

Поступила в редакцию 14.09.2020

Пасс Андрей Аркадьевич, доктор исторических наук, профессор

ФГБОУ ВО «Челябинский государственный университет»

454001, Россия, г. Челябинск, ул. Братьев Кашириных, 129

E-mail: pass_andrey@mail.ru

\section{A.A. Pass \\ INTERACTION OF STATE AGENCIES AND BUSINESS IN THE REPUBLIC OF KAZAKHSTAN DURING THE FINAL STAGE OF THE PRESIDENCY OF N.A. NAZARBAEV}

DOI: $10.35634 / 2587-9030-2021-5-2-186-194$

The article examines the relationship between government officials and entrepreneurs with the emphasis on reducing administrative barriers, strengthening the rule of law in the economy, and increasing the activity of the business community. The article describes multi-circuit system of central and regional republican bodies responsible for regulating economic processes. Special attention is paid to the role of the non-state sector in establishing constructive cooperation between private firms and state-funded organizations. This work provides comprehensive analysis of strengths and weaknesses of the fight against corruption offenses and manifestations of unfair competition. The article describes measures to overcome discretionary decisions, streamline the implementation and control of tax audits. It also provides examples of the abuse of power by government officials when working with businessmen. The article evaluates the effectiveness of electronic portals that helped to resist such attempts. In addition, this work analyzes state's efforts to streamline and simplify customs procedures. It talks about measures to simplify access of enterprises of various forms of ownership to participate in tenders for public procurement. This article provides comprehensive recommendations on the reduction of criminal activity among entrepreneurs and government officials.

Keywords: Republic of Kazakhstan, Presidency of N.A. Nazarbayev, government bodies, business structures, optimization of the business climate, reduction of corruption risks.

\section{For citation:}

Pass A.A. Interaction of state agencies and business in the Republic of Kazakhstan during the final stage of the Presidency of N.A. Nazarbaev // Bulletin of Udmurt University. Sociology. Political Science. International Relations. 2021. Vol. 5, iss. 2. P. 186-194. https://doi.org/ 10.35634/2587-9030-2021-5-2-186-194. (In Russ.)

Received 14.09.2020

Pass A.A., Doctor of History, Professor

Chelyabinsk State University

Brat'ev Kashirnykh st., 129, Chelyabinsk, Russia, 454001

E-mail: pass_andrey@mail.ru 